\title{
The Initial Training of Science Teachers in African Countries: A Systematic Literature Review
}

\author{
Diana Soares $^{1}\left(\mathbb{D}\right.$, Betina Lopes $^{1, * \mathbb{C}}$, Isabel Abrantes ${ }^{2}$ and Mike Watts ${ }^{3}$ \\ 1 Research Centre on Didactics and Technology in the Education of Trainers (CIDTFF), \\ Department of Education and Psychology, University of Aveiro, 3810-193 Aveiro, Portugal; \\ dianarsoares@ua.pt \\ 2 Centre for Functional Ecology (CFE), Department of Life Sciences, University of Coimbra, \\ 3000-456 Coimbra, Portugal; isabel.abrantes@uc.pt \\ 3 Department of Education, College of Business, Arts and Social Sciences, Brunel University London, \\ Uxbridge UB8 3PH, UK; mike.watts@brunel.ac.uk \\ * Correspondence: blopes@ua.pt
}

Citation: Soares, D.; Lopes, B.; Abrantes, I.; Watts, M. The Initial Training of Science Teachers in African Countries: A Systematic Literature Review. Sustainability 2021, 13, 5459. https://doi.org/10.3390/ su13105459

Academic Editors: Lili-Ann Wolff and Pedro Vega-Marcote

Received: 1 April 2021

Accepted: 7 May 2021

Published: 13 May 2021

Publisher's Note: MDPI stays neutral with regard to jurisdictional claims in published maps and institutional affiliations.

Copyright: (c) 2021 by the authors. Licensee MDPI, Basel, Switzerland. This article is an open access article distributed under the terms and conditions of the Creative Commons Attribution (CC BY) license (https:// creativecommons.org/licenses/by/ $4.0 /)$.

\begin{abstract}
This study presents a systematic literature review (SLR) on the initial training of science teachers in Africa based on selected research articles, in the period 2000-2020, that emphasize the importance of surveying knowledge that goes beyond those that historically have a longer path in the building of scientific knowledge, such as that of European or North American countries. The analysis included a total of 31 articles from the Web of Science (WoS) and Scopus databases. The findings indicate a lack of knowledge, or at least visibility, considering the initial training of African teachers, particularly in developing countries. South Africa leads the number of publications. Within the five African countries implied in the SLR the following outputs were identified: (i) a division between teacher education research that is 'place-based' and one that uses (only) 'universal theories' (such as Vygotsky and Bandura); (ii) a tension between the application of student-centered learning and teaching models and more traditional classroom practices. Finally, the majority of articles highlight the importance of investing in further research around teacher education. Based on these outputs the importance of international cooperation in teacher education research articulating theory and practice to ensure a global and local perspective towards sustainable development is reinforced.
\end{abstract}

Keywords: Africa; curricula development; science teacher education; sustainable development; systematic literature review

\section{Introduction: Sustainable Development and Education}

The constant occurrence of attacks against humanity, the current biodiversity crisis, and the increased consequences of climate change urges a necessary global transformation in approaches to science education. New approaches focused on science(s) need to capacitate pupils and citizens of the present and the future to deal with global challenges and truly implement sustainable living in its diverse and complex dimensions [1-3].

This need is recognized not only at the academic level, but also at the political level leading to the emergence of international agendas, such as the United Nations Sustainable Development Agenda 2030, approved on 25 September 2015, which resulted from the work of governments and citizens around the world [4]. Its main purpose is to contribute, globally and by 2030, to the eradication of poverty and gender inequalities, the reduction of inequalities within and between countries, the protection of the environment and the fight against climate change, thereby promoting the prosperity and well-being of all.

This Global Agenda is constituted by 17 goals, one being specific for Education, signaling its central role in social transformation. The 4th Sustainable Development Goal (SDG) aims to "ensure inclusive and equitable quality education and promote lifelong learning opportunities for all" and recognizes therefore the importance in investing in teacher education, including through international cooperation (SDG 4, target 4.c). 
At a more regional level, for example, in Africa, it is important to highlight that the importance of education towards sustainable development is also recognized by the African Union Agenda "The Africa we want: A Common Strategic Framework for Inclusive Growth and sustainable Development" [5]. This Agenda, despite being inspired in the 17 United Nations goals, also assumes the specificities of its own region, defining a longer timeframe, 2063 in order to deal with further challenges particular to less developed African countries. This agenda includes a total of 20 goals and seven aspirations, two of them being the capacitation of African people:

Aspiration 1 "A prosperous Africa based on Inclusive Growth and Sustainable Development", which integrates Goal 2 "Well educated citizens and a competence evolution assisted by Science, Technology and Innovation".

Aspiration 6 "An Africa whose development is people-oriented, relying on Africans as human resources, especially women and young people, and that takes care of its children", which integrates Goal 18 "Youth and children involved and enabled".

Following the 2063 Agenda, and specifically for education, the "Continental Strategy for Education in Africa (2016-2025) emerged [6]. The CESA defines specific objectives, the first, "Revitalize the teaching profession to ensure quality and relevance at all levels", which is associated to 6 intermediate objectives. Considering the aim of the current systematic literature review the following are important to highlight: (a) "Recruit, train, and deploy well qualified teachers as well as promote their continuous professional development with emphasis on instilling core values, results and accountability to learners" and (c) "Develop quality and relevant teaching and learning materials".

\section{Sustainable Development and Teacher Education in Africa}

Presently, the African continent is composed by 55 recognized countries, 54 being members of the African Union. While most African countries have made great advances in policymaking and curriculum reforms, the gap between demand and supply of qualified and capable teachers remains an ever-present challenge [5].

Teacher education in Africa faces challenges that include: (i) poor resources for science teaching; (ii) inadequate number of higher teacher education institutions; (iii) implementation of conflicting educational policies by various regimes that often result in frequent structural changes; and (iv) politically motivated curriculum reforms and large classes $[1,5,7]$. Although there is a vast amount of literature on the concerted efforts that have been made by African countries towards curriculum reforms and teacher education in general, only a few of these have been explicitly devoted to Science (Teacher) Education [7,8].

In an article pre-dating our review entitled "Science Education in Botswana", [9] listed a number of obstacles to the teaching of science in that country, such as: inadequate qualified science teachers; dependence on a large number of expatriates without educational qualifications; use of English as a second language for scientific instruction; and an inadequate number of scientific laboratories. Those obstacles can still be seen in the papers we have reviewed since that time.

This is a systematic literature review focused on initial training of science teachers (in particular from natural sciences, biology, and geology) in African countries. Several studies emphasize the importance of surveying and disseminating local knowledge produced by research in countries that historically have less research tradition than, for example, European countries or countries from North America [10,11]. In fact, these aspirations integrate the African Union Agenda 2063 [5], specifically at the level of Aspiration 2 ("African Renaissance") and Aspiration 7 (Africa as a strong and influential actor worldwide).

The mapping of existing research involving African countries is intended to provide greater visibility of research carried out in sub-Saharan Africa and, thus, to enhance its role in the international sphere. By discussing the outputs, we expect to contribute to a broader reflection considering the importance of sharing of curricula from different countries [12,13], and cultural clusters [14,15], in order to sustain an enriched global vision about science teacher education [2]. 


\section{Materials and Methods}

The systematic literature review was conducted by accessing two international databases (Scopus and Web of Science). The following research questions (RQ) guided the process:

(1) What are the specific contexts in which research around Initial Teacher Education was performed in African countries between 2000 and 2020 (specific development, scientific area, higher education institutions, specific teacher training curricula)?

(2) What are the main characteristics of the research developed (main topics and conceptual models)?

(3) What are the main outputs/recommendations of the research?

This study is integrated into a broader individual doctoral project focused on investigating how future biology teachers are being trained in different national and cultural contexts (Portugal, Angola, and the UK) and systematizing this information seeks to improve a more sustainable and equitable decisions considering the educational policy of biology initial teacher training.

\subsection{Data Sources and Search Strategies}

To identify the articles focused on these issues, we carried out a literature search in November 2020 in two electronic databases (Scopus and Web of Science). These are the two most highly valued databases for the international scientific system (evaluation and funding). We identified peer-reviewed studies with articles written in English or Portuguese. To identify eligible articles, we defined the following search terms: (teacher education) AND (Africa); AND (science teacher). The timeframe was between the years 2000 and 2020. A total of 200 articles were thus recognized in our initial search.

\subsection{Inclusion and Exclusion Process}

After removing duplicates, 196 unique articles remained and were further screened, by reading the title and abstract, based on the initial inclusion criteria. This process led to a set of 35 articles that were subjected to full-text review. The other 161 articles were excluded because they included in-service teacher education and not initial teacher education, focused on students (and not teachers) and, despite including reference to "Africa", were not focused on teacher education from African countries, or empirical evidence of these countries.

From this point, the 35 articles were subjected to a full-text review considering the research questions. During this process, additional criteria were added concerning the characteristics and comprehensiveness of the frameworks. Table 1 includes the final inclusion and exclusion criteria. After the full-text review, 31 articles were considered to be eligible for the present review (See Appendix A Table A1). Reasons for exclusion and an overview of the search process can be found in the PRISMA diagram (Figure 1). The listed articles were organized by year of publication, coded with a number and thematic content analysis was based on analytical procedures developed by [16].

Appendix A presents the papers comprised in the systematic review $(n=31)$ and the codification (number of the paper) used to identify each paper, which will be included in the next section to discuss the results of the analysis.

Table 1. Inclusion and exclusion criteria in published articles.

\begin{tabular}{ccc}
\hline Criteria & Inclusion & Exclusion \\
\hline Time frame & Articles between 2000-2020 & Articles published before 2000 \\
Language & Articles in Portuguese and English & Articles in other languages \\
Context & Articles about Africa & Articles about other regions \\
Sector framework & Articles that included initial teacher education & Articles that included in-service teacher education \\
Structure & Articles that included scientific article structure & Articles that included unclear procedures \\
& & Book chapters/dissertations \\
\hline
\end{tabular}




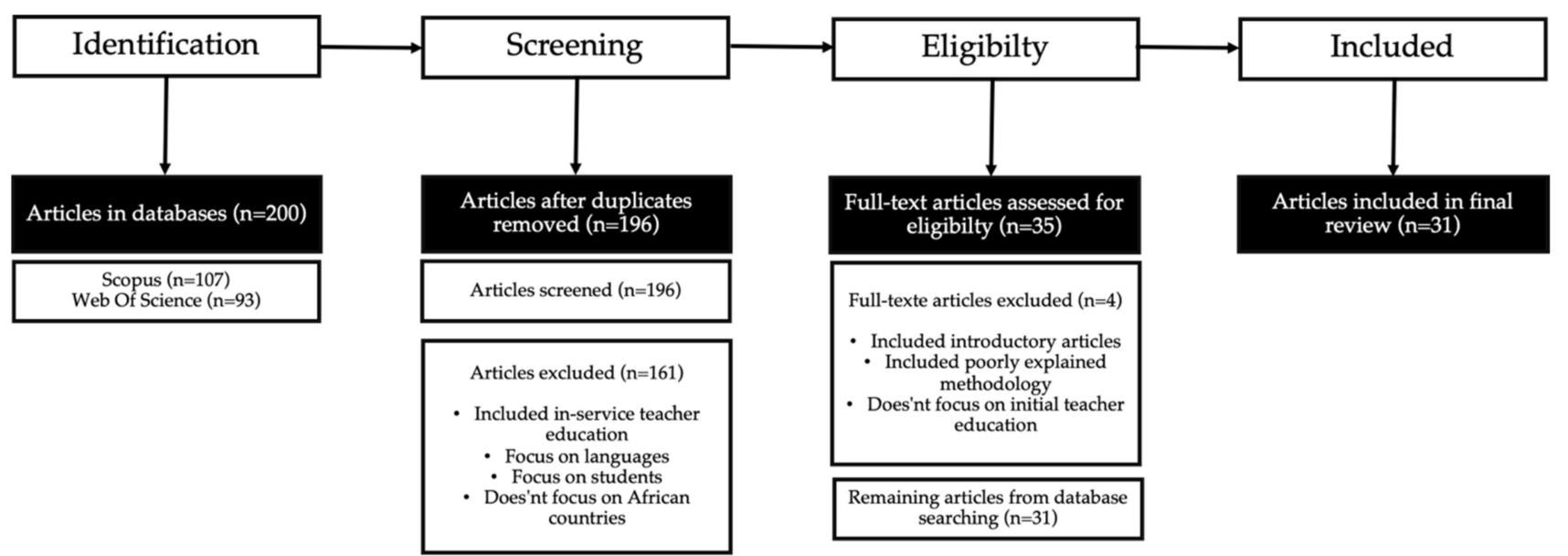

Figure 1. Reporting items for the systematic literature review of initial training of science teachers in African countries (adapted the Preferred Reporting Items for Systematic Reviews (PRISMA) statement).

\subsection{Characteristics of Included Studies (Corpus)}

The year with the most studies that entered our search is $2019(n=7)$ followed by 2015 $(n=5)$, as shown in Figure 2. Our results reveal a large oscillation of articles on the subject in the last 20 years.

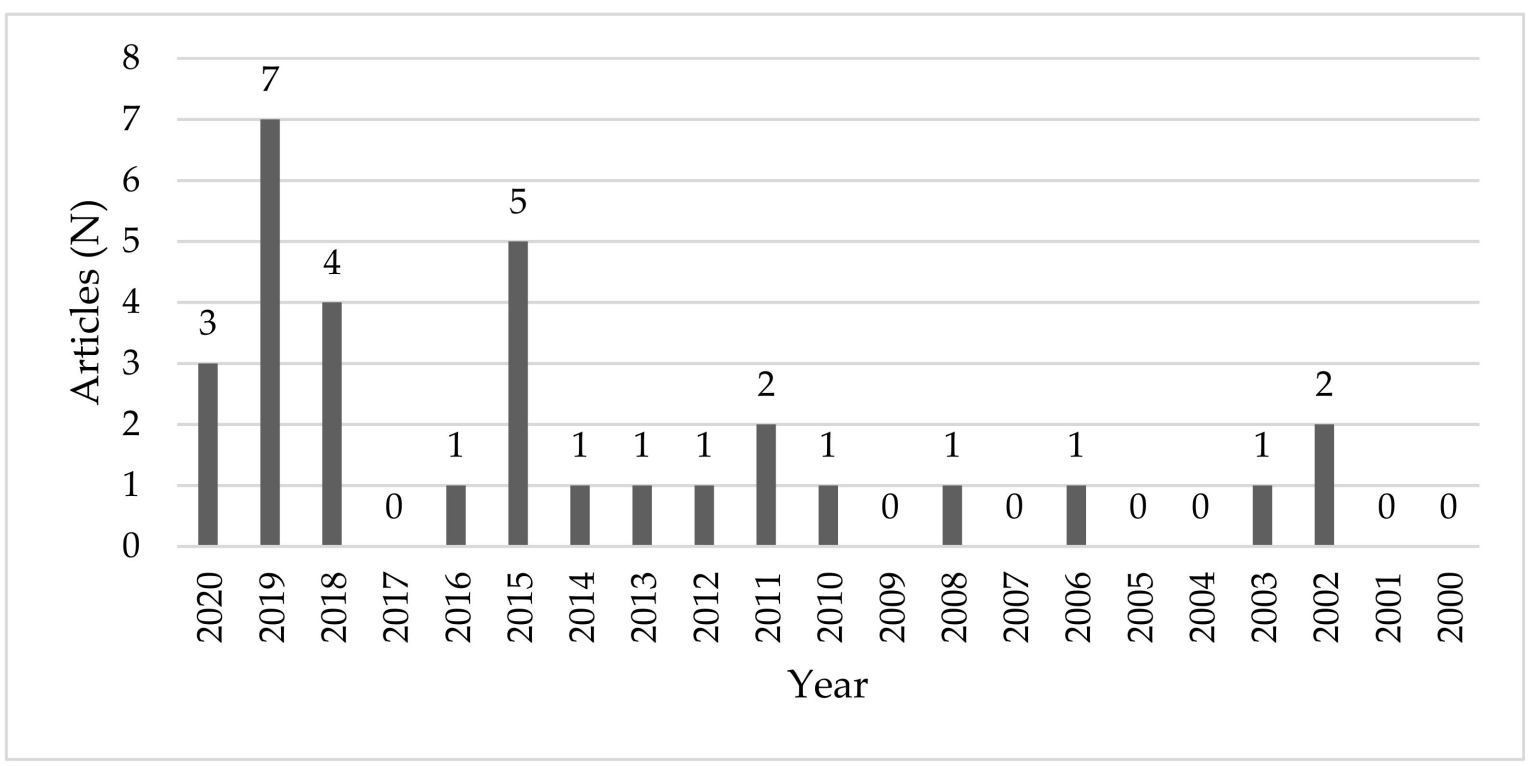

Figure 2. Frequency of publication per year.

Regarding the methodology, we found a predominance of qualitative studies $(n=24)$.

Concerning the journals, 18 journals published 31 papers on the subject under analysis (Figure 3), which highlight the enhanced relevance of the theme in various areas of knowledge.

The analysis of the 31 articles (Table 2) showed that most of the articles gather authors from the country where the study was developed.

The studies identified with affiliation from 2 countries (A6, A22, A23, A24, A30) are comparative studies between countries (A6, A22 and A24) or with researchers from different countries where the country in the context of research is one of them (A23, A30). 


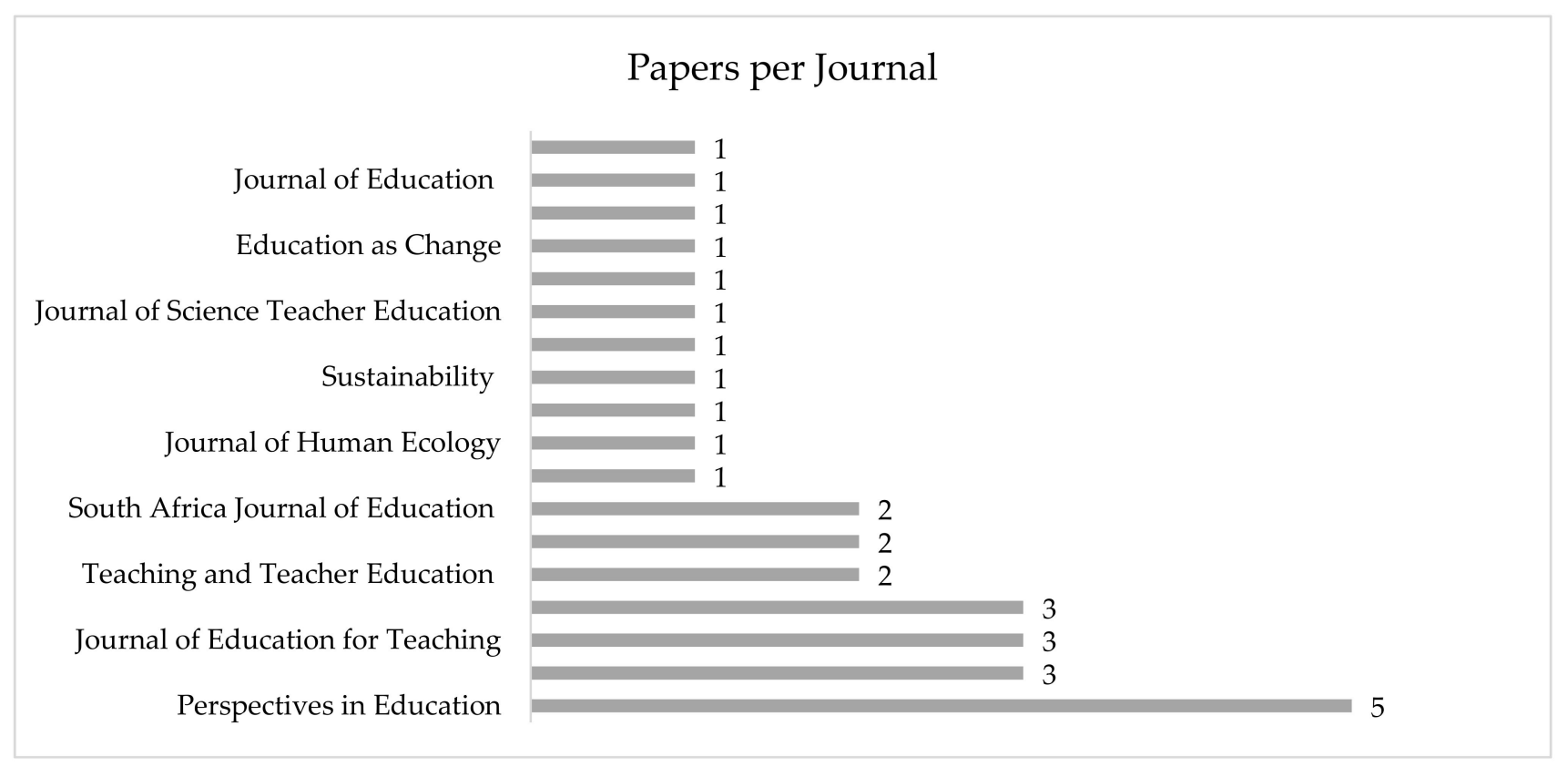

Figure 3. Frequency of papers per journal.

Table 2. Description of articles' affiliations.

\begin{tabular}{cccc}
\hline Category & & $\boldsymbol{n}$ & $\%$ \\
\hline Affiliations & South Africa & 22 & 71 \\
& Nigeria & 2 & 7 \\
& Angola & 1 & 3 \\
& Ghana & 1 & 3 \\
& $>2$ countries & 5 & 16 \\
\hline
\end{tabular}

\section{Results and Discussion}

In this section, we present the results of the aforementioned systematic revision process, organized according to the research questions that guided our search and analysis.

3.1. What Are the Specific Contexts in Which Research around the Initial Teacher Education Was Performed in African Countries between 2000-2020 (Specific Development, Scientific Area, Higher Education Institutions-Specific Teacher Training Curricula)?

3.1.1. Countries-Specific Developing and Matching between Affiliation and Practice Professional, School Levels

Most of the contexts that emerged in this literature review focus on South Africa $(n=23)$ (A3, A7-A19, A21). There are also three comparative studies between South Africa and two other countries. In one of the studies (A6), the comparison is between the South African context and that of Finland, in A22 the comparison is between South Africa and Zimbabwe and in A24, the comparison is between the UK and South Africa.

Other studies (A5, A30) are focused on Ghana and A2, A25 on Nigeria. Only one study is on the Angolan context (A1) and another (A23) on Tanzania (Figure 4).

Taken these results into consideration, it is possible to verify that, of the 54 countries belonging to the African Union, only $5+1$ countries were in the area of initial teacher training (sciences).

In 2019, there is a major research trend by South Africa with a relatively high Human Development Index (HDI) (0.709). This can be informative about the importance that is given in the country to the initial training of teachers and to research in this area. 


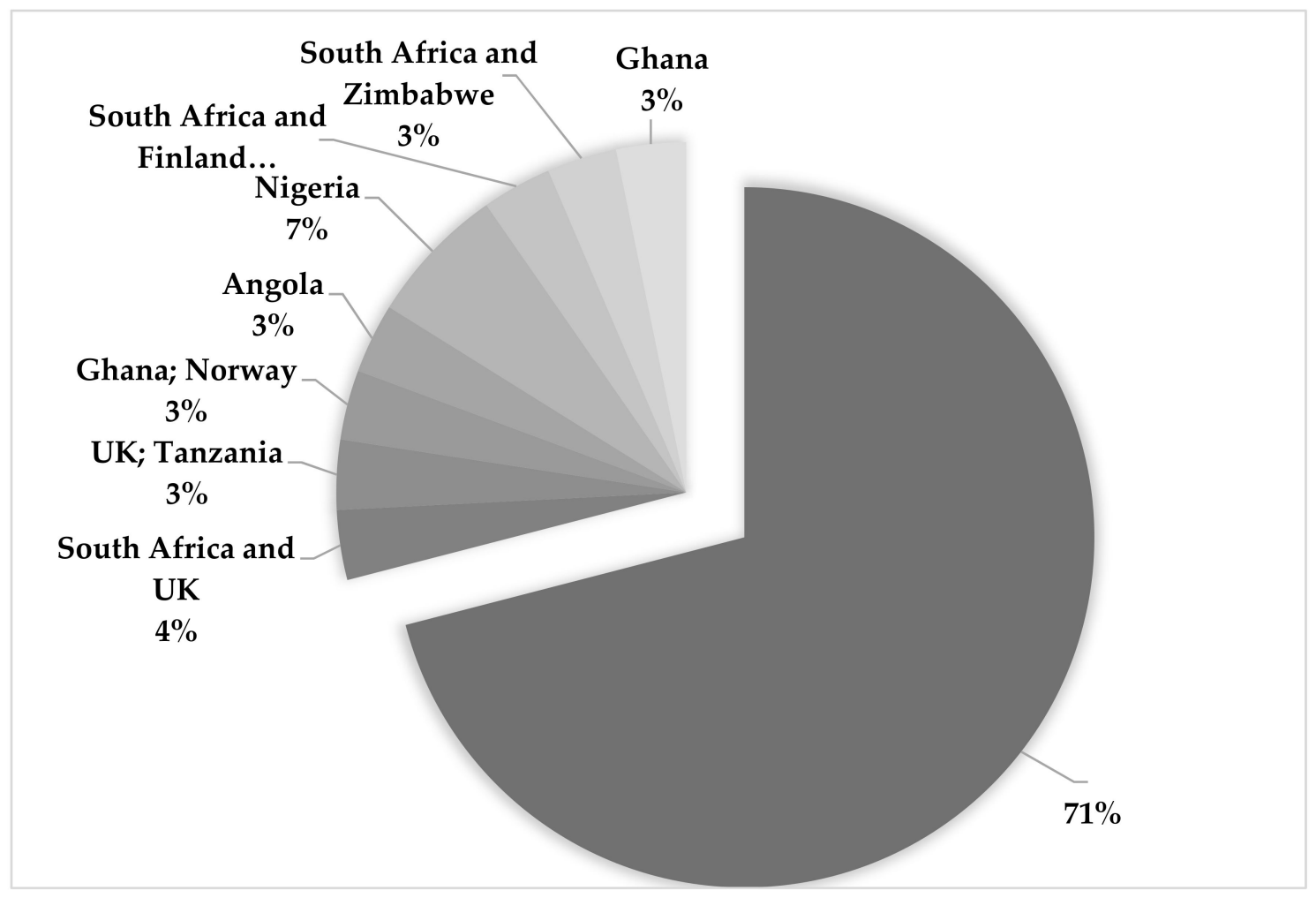

Figure 4. Distribution of corpus articles by the countries where the investigation takes place.

Countries such as Ghana, with HDI (0.611), Angola (0.581), Nigeria (0.539), Tanzania (0.529), and Zimbabwe (0.571) appear in comparison to South Africa. This comparative article (A22) was published in 2013 and the authors report that it was shaped to find similarities and differences and later make inferences. The article was produced by an author from Zimbabwe and two authors from South Africa, signalizing academic cooperation among African countries, and between African countries and countries from other regions, within the thematic of (science) teacher education. However, not as much as it would be desirable.

\subsubsection{Scientific Area}

Of the set of articles analyzed $(n=31), 13$ refer specifically to the initial training of science teachers (biology, mathematics, physics...) (A1, A3, A5, A8-A10, A12, A13, A15, A17, A18, A22, A26), involving teachers from Angola, South Africa and Zimbabwe. Most of them $(n=16)$ are on initial teacher training in general $(\mathrm{A} 2, \mathrm{~A} 4, \mathrm{~A} 6, \mathrm{~A} 7, \mathrm{~A} 11, \mathrm{~A} 16$, A20, A21, A23-A25, A27-A31) and involve teachers from Nigeria, Ghana, South Africa and Tanzania. In these, some topics such as teachers' experiences during pedagogical practice (A2), comparison between teacher learning and student learning (A4) and the link between theory and practice in teacher education (A20) are discussed. Finally, two articles on the initial training of primary school teachers (A14, A19) both in south African context. In these studies, there is a concern with the accessibility to the knowledge of the most disadvantaged contexts since the early years and encouragement to the critical and reflective thinking of teachers (Table 3).

Table 3. Distribution of corpus articles by the scientific area.

\begin{tabular}{ccc}
\hline Scientific Area & $\boldsymbol{n}$ & $\%$ \\
\hline Teacher education & 16 & 52 \\
Science teachers & 13 & 42 \\
Primary teachers & 2 & 6 \\
\hline
\end{tabular}




\subsubsection{Involved Higher Education Institutions}

Twenty-nine studies were conducted in the context of a higher education institution with initial teacher training courses (A1-A4, A6-A19, A21-A31), being one of them (A5) within a pedagogical school and another (A20) on the partnership between a higher education institution and a pedagogical school.

\subsection{What Are the Main Characteristics of the Research Developed (Main Topics and Conceptual Models)?}

According to the content analysis developed, a great diversity of concepts associated with the initial training of teachers in Africa emerges in the selected corpus $(n=31)$. The associated concepts were grouped into four major groups (Table 4). In this section, we highlight the concepts associated to the first three groups: (i) professional and pedagogical development and teacher identity; (ii) teaching practice and learning models and (iii) curricula/curriculum. These concepts are directly related with the ongoing doctoral project, in which this literary review is integrated.

Table 4. Main categories of concepts associated with initial teacher training in Africa.

\begin{tabular}{ccc}
\hline Category & $n$ & $\%$ \\
\hline (i) Professional and & & \\
pedagogical development and & $5+4+3$ & $16+13+10$ \\
Teacher Identity & 5 & 16 \\
(ii) Teaching practice & $3+1$ & $10+3$ \\
Learning Models & 3 & 10 \\
(iii) Curricula/curriculum & 3 & 10 \\
(iv) Others (e.g., Quality; & 3 & 10 \\
Critical reflections; & 1 & 2 \\
Sustainable development) & & \\
\hline
\end{tabular}

\subsubsection{Professional and Pedagogical Development and Teacher Identity}

One of the structuring concepts that emerges within the corpus under analysis is the professional development associated with the identity of the teacher. Referred to and used as a guide of the research, this appears in articles (A3-A5, A7, A11, A12, A30).

In articles $\mathrm{A} 3$ and $\mathrm{A} 12$, the authors report the professional development and competencies through the use of the instructional model 9E. This model, developed originally by Ramaligela et al. (2019), provides teachers with 9 phases: (I) elicit seeks to request prior knowledge from students. For example, a teacher can use different modes of classroom interaction, such as pre-assessment and multimedia strategies to assess students' prior knowledge; (II) elaboration, connects everyday experience/knowledge to a new concept. For example, pre-service teachers could use learners' previous knowledge, personal experiences or local knowledge to build their understanding of the new concept; (III) explanation, continuously provides explanations of different concepts to enhance learners' understanding. For example, pre-service teachers might use different modes (argumentative, justification, descriptive or interpretive) to explain different concepts that are either correct or incorrect; (IV) exploration, accurately introduces new concepts, processes or skills in a coherent manner to reduce confusion. Moreover, pre-service teachers could use different modes (conceptual connection, procedural connection or equivalent representation) to present new concepts; (V) evaluation, continuously assesses learners' understanding, which must take place during all interactions with learners in all presentation phases. In addition, pre-service teachers could use different evaluation modes (practical task, a concept-focused task or a lesson-outcome evaluation task) to assess learners' understanding of the concepts; (VI) enlightening, using topic-specific strategies. Again, pre-service teachers might use different strategies (multimedia representation, an object demonstration and simulation methods) to teach different concepts; (VII) engagement, entails continuously involving learners throughout the lesson as active participants, which 
helps them to build conceptual understanding. Furthermore, pre-service teachers could use different modes (thought-provoking questions, problem-based methods, demonstration or discussion methods) to stimulate learners' curiosity, interest and attention; (VIII) exchange, using learners' ideas to identify a teachable moment or an unexpected opportunity to convey new knowledge. For example, pre-service teachers could use learners' responses to build understanding of different concepts and to correct learners' misconceptions; and (IX) enclosure, summarizing the concepts. Pre-service teachers could use various modes (wrap-up, nutshell or a continuous summary), to conclude the lesson.

In article A4, also focused on professional development and identity of the teacher, the author states that the study is based on Wenger (1998), articulating the arrest and social participation. Based on this analysis, the authors report that according to Wenger (1998), the social community of the faculty shapes the learning experiences of student-teachers, but this participation also changes the community itself: "the transformative potential goes both ways" (as cited in Buckler, 2020). Second, it is based on the idea of learning as a "process of becoming", a formative learning experience through which the identities of teachers are shaped. The possibilities for change are managed by past learning of student-teachers and existing knowledge, as well as by negotiation within the community.

In article A5, the authors explore the learning process of student teachers throughout the zone of proximal development using, as theoretical structure, the concept of PDZT-proximal development zone of teachers, developed by Warford (2011). This author proposed that student learning can be optimized by exposing it to scenarios that assume students know more than they really know (as cited in Van Wyk, 2019). The resulting cognitive dissonance becomes the basis for developmental change and is determined by 'prolepsa' (Van Lier, 2004) that defines the ideal distance between the potential development and the actual development of a student teacher within the PDZT. According to the authors' idea, based on Warford (2011), the PDZT is divided into four stages: (i) self-service where the teacher educator provokes the beliefs of teachers about teaching and their previous knowledge. Student teachers enter their teacher training programmes with the "baggage" of observing the teaching of their teams during their own schooling, the so-called learning of observation; (ii) teacher-assisted where students experience field-based demonstrations of how innovative teaching practices occur in classrooms; (iii) internalization recognizing that students struggle to employ the most student-centered pedagogies and are quick to discard them for the more familiar old customs and (iv) recurrence, which could be designated to as the "theory in practice phase" (cited in Van Wyk, 2019) and as referred by $[14,15]$. This is where students confront field-based school experiences and where the accommodation of new incursions into conceptual understanding occurs through a process of stress and discomfort.

In Article A7, according to Kent et al. (2012), mentoring should be an integral part of the teacher training process for teacher-students to experience success in their journey to professionalism. This improves the professional skills of the student-teachers and familiarizes them with the sociocultural structure (as cited in Ngibe, 2019). Leshlem (2012) sees the mentoring process as part of the teacher's professional development (as cited in Ngibe, 2019).

In article A11, the position is that teachers need to be socialized both in the concepts within educational theory and in the contexts of teaching and learning from the perspective of a practitioner. Some argue that attempts to define a professional knowledge base of concepts for teaching undermine the importance of artisanal knowledge and the art of teaching and potentially ignore the ethical scales of teaching (e.g., Hargreaves \& Goodson, 1996; Sockett, 2008) (as cited in Christiansen, 2018). The argument from this perspective is that teaching is essentially a practice that is learned through experience and through reflection within and about practice and that learning to be a teacher is to develop practical wisdom in the classroom. On the other hand, the argument is that good teachers are based on a reservoir of academic knowledge and diagnosis and not only on intuition and everyday experience. Ball and Forzani (2009) argue that the nature of teaching practice is 
an intricate and unnatural work and therefore requires deliberate training to make choices using professional judgment (as cited in Christiansen, 2018).

In article A12, the authors suggested that there are three distinct aspects of the professional knowledge of teachers that work in a complementary way. These are situated in a permanent or practical wisdom, technical knowledge of how to plan and control the learning process, and the ability to reflect critically, and it is vital that teachers acquire and develop all these three aspects. Similarly, the authors' position is that professional knowledge implies more than practical wisdom, which is learned through experience and through the learning of more expert colleagues. Practical knowledge or knowing how is strengthened when inferences are made from a systematic body of knowledge, not just from everyday experiences.

In article A30, the authors note that the notion of the development of teaching identity has been pointed out as important in teacher thinking and classroom actions. Research on the identity of the teacher's role points to a contextualized sense of oneself, which is often in tension with an external and professional sense of oneself, shaped by culture, context and circumstance such as [14,15]. The idea of identity as a sense of one's own is thought to play a crucial role in the formation of teacher behavior. This formulation of teachers' vision of themselves and identity evolves through the cumulative influence of several factors that include the home environment, parents, teachers, and socioeconomic and political factors. The characteristics and input qualities of the typical beginner student teacher are important indicators of the quality of teachers trained at the exit point and their continuous long-term commitment to the profession.

\subsubsection{Curricula/Curriculum (A6, A9, A27)}

For Apple (2004) [17] and Santomé (1998) [18], the curriculum goes beyond what is specified, while knowledge that tends to connect to certain interests of individuals of social groups, politicians and reflect on the modes, symbols, routines, school functioning, which implicitly enhance learning. This dimension becomes even more significant when one recognizes the relationship between the curriculum and the individual and collective identity of the students $[19,20]$.

In article A6, the authors take Shulman as the basis and assume that the curriculum implemented is therefore not necessarily identical to the intended curriculum. The definitive curriculum achieved refers to the experiences of the students and is derived from the learning and teaching processes they had encountered. The intended curriculum also mentions the knowledge of content (subject), which includes conceptual, factual and procedural knowledge in a specific domain, such as mathematics education. A teacher also needs to understand the nature of knowledge that is the epistemological and ontological aspects of the subject.

In Article A9, according to Ornstein and Hunkins (2014), the reorganization of content knowledge in the context of the curricular design of broad fields implies the fusion of fragmented and compartmentalized content based on discipline of subjects related in areas of learning (as cited in Booi, 2019). Proponents of this trend praise this approach to curriculum development to facilitate the hybridization of content and knowledge both in the construction of knowledge and pedagogy, allowing students to make connections of the related topics and conceptual knowledge among disciplines. Fogarty (1991) proposes several models for the implementation of knowledge integration: the integration of knowledge within the discipline could be carried out through "connected" models and "nested" models (as cited in Booi, 2019). Such models emphasize interconnections between disciplines by connecting concepts, skills, and ideas related to a topic. In the case of science, aspects of geology, astronomy and biology could be dealt with under a single unifying theme or organizing principle. For knowledge integration across disciplines, the following models are recommended: sequencing, shared, webbed, and integrated. These models may differ in practice, but they all focus on the crossing of epistemic and theoretical boundaries in the broadly identical process of knowledge composition and pedagogy in curriculum 
development. In the sequencing model, knowledge is organized into a coinciding sequence while in the shared model entails clustering ideas, concepts, and skills from overlapping topics or themes. The focus in this model is on key concepts, attitudes, skills, and ideas, which could be duplicated unnecessarily if taught in separated, distinct disciplines. The webbed model requires the organization of knowledge into broad themes or units, which are generic or provide fertile ground for development of conceptual knowledge, emerging from common ground, much like sprouts or shoots, and the threaded model emphasizes the identification of big ideas to be linked up for the acquisition of conceptual knowledge, cognitive, social, and affective skills across disciplinary divisions.

In Article A27, the authors comment the need to integrate the HIV (Human Immunodeficiency Viruses) theme into classrooms integrated into contexts where HIV exists in large numbers.

\subsubsection{Learning Models and Teaching Practice (A5, A7, A8, A14, A21, A25, A26)}

Teachers can be conceptualized as learners of a pedagogical practice. Therefore, their learning experience might be problematized under the scope of learning theories. For example, studies A5, A7 and A8 underline the cognitivist learning model of Bandura (1977) and the socio constructivist model of Vygotsky (1978).

Article A7 refers to Bandura's social cognitive theory (1986), which suggests that people learn principally through observation. In the same alignment student-teachers observe their mentors and by doing this they learn some skills and tactics on how to deal with all situations in the classroom during their practical teaching. This theory focuses on interactions between personal factors, behaviors and the environment (as cited in Ngibe, 2019). Pre-service teachers during their pedagogical practice in different host schools interact with different people, with different behaviors and personalities and from different socioeconomic and cultural backgrounds $[14,15]$. Thus, there will be challenges that they must face and they must strive to learn how to transform such challenges so that they learn from their attempts to turn challenges into empowerment possibilities and strengths before graduating as professional teachers. In the same article and in A5 and A8, the authors sustain their argumentation on Vygotsky's (1978) socio constructivist theory, which highlights that the construction of knowledge is the process that occurs in social contexts. Pre-service students learn by observing their mentors, while in turn pre-service teachers teach students how to implement what they have observed and learned from the university. Therefore, and in order to enhance learning, it is recommended that teachers, studentteachers, and the community build up its relationships that are fundamental for learning, as learning is influenced if there is collaboration between teachers, students and parents. These are the crucial stakeholders in classroom learning where student teachers and the community are the central issues influencing learning.

Finally, some studies sustain learning models regarding Teaching practice, highlight that student teachers are not adequately prepared to teach, particularly in disadvantaged schools, signalizing a gap between the preparation received in the lecture room and teaching realities encountered in the field [14,15].

\subsection{What Are the Main Outputs/Recommendations of the Research?}

In this section, the data are presented by country, in descending order of number of articles. The option of organizing by country is that it allows us to access the main results by country and thus systematize the most interesting results for the study to be developed.

South Africa (A5, A6, A8, A9, A11, A12, A14, A17, A20, A21, A24, A26, A28)

Some studies (A8, A14, A21) illustrate that future teachers are not adequately prepared to teach in previously disadvantaged schools serving the majority of students in South Africa, and that there is a disjunct between the preparation received in the lecture room and the realities found in the field. The data indicated that the pre-service teacher did not have the opportunity to be exposed to teaching in rural schools during his/her pedagogical practice and the curricular content of the degree in education did not include aspects related 
to rural education, making it difficult to retain teachers in rural schools. In study A21, the following recommendations are made that modules have a specific focus on teaching in rural schools are included in the curriculum and each student is required to pass at least one session of practical teaching in the course in a rural school. Colleges of education must ensure that student teachers have teaching experience in rural schools. It is also recommended the establishment of incentives to teachers who teach in rural schools.

In A5 future teachers' difficulty when entering the real context of teaching are explored. Authors state that students' teachers considered the pedagogical school's approach very beneficial for their development of scientific and pedagogical knowledge, highlighting the benefits of scientific research strategies and the application of pedagogical theories, much in alignment with A28, where authors specifically argue that previous teacher knowledge should be integrated in the research strategies. Student teachers emphasized that the students at the school, through their questions, offered opportunities for their professional development to take place. This fact is corroborated by the A20 study, which showed positive effects of real context experience in pedagogical schools, referring its importance in improving teacher training, serving as a bridge between the academic and university preparation of student-teachers and the practical needs of the teaching profession.

To address some of the problems associated to professional development of student teachers, study A12 indicates that instructional practice " $9 \mathrm{E}$ " can be a valuable tool for improving specific pedagogical content knowledge (PCK) in the field of mathematics and technology education disciplines. Therefore, the study proposes further research into the instructional model "9E" that could be used as field specific PCK in the fields of mathematics, science and technology.

Study A24 sought to understand the main obstacles in the UK and South Africa on the teaching of controversial issues in the context of initial teacher training. The data suggest that there are still serious obstacles in both countries to teach controversial issues in schools and in preparing education teachers to teach about controversial issues. Another problem highlighted is the issue of multilingualism in the classroom [14,15]. To overcome these issues, study A26 presents five elements of good practices for these teacher educators: (i) use of code switching; (ii) creation of a reliable environment in the classroom; (iii) use of one (instead of two) means of instruction, namely English, (iv) use of linguistic metaphors that the languages present in the class potentially predict for use in mathematics and; (v) creation of an awareness of the multilingual context in which pre-service teachers would teach at the end of their qualification.

Article A9 reports the conclusions that emerged from documental analysis to science teacher education course programs of six universities and interviews to science teacher educators emphasizing a lack of coherence between the course curricula and the conceptual framework associated to PCK, particularly considering interdisciplinary teaching enhancing leading to additional challenges to 'produce' qualified science teachers.

To improve initial training in South Africa, in study A6, the authors sought to insert in South Africa the teacher training model used in Finland. After applying this model in context, the authors conclude that an innovative model of teacher education can be reinvented in a significantly different context and add new dimensions to the original. This brings us to the intersection of contexts and the inclusion of international cooperation for teacher training.

Finally, Articles A17 and A22 argue towards the importance of investing in teacher quality education, as well as professional teacher status, since no educational system can exceed the level of its teachers, hence the crucial role of investing in teachers' ability to promote scientific literacy.

\section{Ghana (A4, A30)}

In the Ghanaian context, the authors of study A4 reveal that the teacher must have specific skills to practice their profession. They stress their intellectual capacity, stating that they should be willing to acquire knowledge through involvement with tutors, peers and learning materials. They also highlight the reputational capacity, where it is desired 
that the teacher can be seen as a model and, thus, have a positive reputation. Finally, they mention the ability of an agent, where the teacher should have the freedom to do things differently and adapt to their acting context and to their students. The study shows how understanding different perspectives on valued "beings and actions" of teaching can help to reinterpret and reimagine processes to "become" a teacher who has practical application at the political and institutional level. According to the authors of article A30, teachers in Ghana follow a teaching career in the expectation of a more lucrative job. The authors consider that ways should be found to include a greater sense of commitment to teaching, involving themselves with the positive values that trainees have about teaching in the discourse of teacher education.

\section{Nigeria (A2, A25)}

In the Nigerian context and based on study A2, there is little representation of women in education, especially in rural areas. The authors point out that few girls attend schools, being main reasons the lack of school resources and financial difficulties of families. The authors suggest that to increase the quality of teacher education it is necessary to look at gender equality. In the same context, the authors of A25 report the need to go beyond the growing number of student-teachers, to improve the quality of teacher education, also paying attention to the outside of college.

It is emphasized the need to teach critical thinking skills to be teachers and their characteristics were discussed. It was also raised that some strategies could be adapted to the teaching of critical higher education skills and the likely challenges could be encountered. Critical thinking has been recommended to be purposely included in all teacher training programs in Africa as part of the general studies course and in all teaching disciplines and methodology courses. The authors suggest that, for effectiveness, a long-term approach and institution should be adopted, and workshops should be organized to train teachers.

\section{Angola (A1) \& Tanzania (A23)}

The study described in A1 concludes that the sustainable development is not yet a concern in the initial curricula of biology teacher training in Angola. Curricula still focus (only) on national and local environmental/social problems. It is necessary to rethink the initial training of teachers for a more sustainable world and, therefore, to promote the discussion of this theme within the same institution and review the curricula of Teacher Education, integrating the goals of and aspirations associated to SD political agenda, both from UNESCO and African Union. Within the study of Tanzania, the need to invest and restructure initial teacher education is also emphasized.

In summary, some of our results converge directly to the conclusions of $[14,15]$ namely: (i) the presence of teacher education programs that are not related to professional realities, such as rural schools (e.g., A8); (ii) the strong need in making the science teaching contextualized in students' daily life (e.g., A21); (iii) the need for pedagogical practices which are more focused on children, and not (only) teachers, this is being based on students experience and surrounding community and not just books; (e.g., A4); (iv) access remains uneven considering teacher education, as well as professionalization, severe infra-structure problems and well as poor governance is also highlighted (e.g., A2 and A25).

\section{Final Considerations: Main Research Conclusions, Limitations and Further Steps}

This paper aimed to develop a systematic review on initial training of science teachers in Africa in order to map the main conceptual models and research outputs associated to this thematic in this specific region. The process identified a total of 31 eligible articles, signalizing South Africa as the country where most research on these topics has been developed in the last twenty years. In fact, of the 55 countries that belong to the African continent, in this systematic literature review (SLR) research from only 5 African countries emerged. These outputs lead to the following interpretations: (i) the need to invest in [more] research around teacher education from other African countries, in particular developing countries; and (ii) the need to include more network research within African countries and countries from different regions towards enriched global perspectives. However, it must 
be considered that the SLR was done only in two languages (Portuguese and English). Further steps should include the identification of research from other language and other data-basis, in order to access a truly global map of educational research about teacher education in Africa. The follow-up tasks will be: (i) the use of snowball techniques in order to identify more studies, consulting the reference list of the selected articles. The use of social networks, such as ResearchGate may also be useful in the localization of African education research, which still seems to be underdeveloped and/or of difficult to access; and (ii) deepen the analysis of the identified studies by characterizing the methodological approaches used as well as to frame the existent outputs with other factors (curricular reforms) cultural clusters [14,15], human development index, and others.

Despite the above-mentioned limitations, results suggest that higher education institutions in Africa are concerned about how to improve the initial training of their teachers.

The major results associated to the five African countries present in the SLR are the following: (i) a division between the research of teacher education that is "place-based" and one that uses (only) "universal theories" (such as Vygotsky and Bandura); and (ii) a tension between the application of student-centered learning and teaching models and classroom practices [14,15]. Specific challenges also include: (i) lack of infrastructures; (ii) gaps between the conditions that student-teachers have during their higher education course and then the professional context where they work (particularly in rural areas); (iii) fragilities of course programs; and (iv) social and environmental challenges. It became evident that educational research is sustained on conceptual models common to European and American educational research, much associated to the founding theorists (such as Vygotsky and Bandura). Nevertheless, there are other theoretical models (e.g., 9E instructional model), not so common in European and Anglo-Saxon contexts, which discussion could enrich teacher education in these specific regions, signaling its potential for mutual enrichment strongly in alignment with the indicative strategy of Goal 4 from SDA that recommends international cooperation within teacher education. Ensuring sustainable development for future generations requires developing and implementing innovative initial training curricula for science teachers.

Author Contributions: Conceptualization, B.L. and D.S. methodology: D.S., B.L. and M.W. formal analysis, D.S. writing—original draft preparation, D.S.; writing—review and editing B.L., M.W., I.A. \& D.S.; supervision: B.L. \& I.A. All authors have read and agreed to the published version of the manuscript.

Funding: This work is funded by National Funds through FCT-Foundation for Science and Technology, I.P. under project UIDB/00194/2020 and CEECIND/03328/2018. It is also carried out within the R\&D Unit Centre for Functional Ecology-Science for People \& the Planet (CFE), with the reference UIDB/04004/2020, with financial support from FCT/MCTES through national funds (PIDDAC).

Institutional Review Board Statement: Not applicable.

Informed Consent Statement: Not applicable.

Data Availability Statement: Not applicable.

Conflicts of Interest: The authors declare no conflict of interest. 


\section{Appendix A}

Table A1. Codification of Articles included in the Systematic Literature Review of initial training of science teachers in African countries.

\begin{tabular}{|c|c|c|c|c|c|}
\hline Code & Year & Authors & Journal & Title & Reference \\
\hline A1 & 2020 & $\begin{array}{l}\text { Chisingui } \\
\text { Costa }\end{array}$ & Sustainability & $\begin{array}{c}\text { Teacher education and sustainable } \\
\text { development goals: A case study with } \\
\text { future biology teachers in an Angolan } \\
\text { higher education institution }\end{array}$ & [8] \\
\hline A2 & 2020 & $\begin{array}{l}\text { Humphreys, } \\
\text { Dunne, } \\
\text { Durrani, } \\
\text { Sankey, } \\
\text { Kaibo }\end{array}$ & $\begin{array}{l}\text { Teaching and } \\
\text { Teacher Education }\end{array}$ & $\begin{array}{c}\text { Becoming a teacher: Experiences of female } \\
\text { trainees in initial teacher education } \\
\text { in Nigeria }\end{array}$ & [21] \\
\hline A3 & 2020 & Ramaligela & $\begin{array}{l}\text { International } \\
\text { Journal of } \\
\text { Technology and } \\
\text { Design Education }\end{array}$ & $\begin{array}{c}\text { Exploring pre-service technology teachers' } \\
\text { content and instructional knowledge to } \\
\text { determine teaching readiness }\end{array}$ & [22] \\
\hline $\mathrm{A} 4$ & 2020 & Buckler & $\begin{array}{c}\text { Compare: A } \\
\text { Journal of } \\
\text { Comparative and } \\
\text { InternationalEdu- } \\
\text { cation }\end{array}$ & $\begin{array}{l}\text { Being and becoming in teacher education: } \\
\text { student-teachers' freedom to learn in a } \\
\text { College of Education in Ghana }\end{array}$ & [23] \\
\hline A5 & 2019 & $\begin{array}{l}\text { Van Wyk, } \\
\text { De Beer }\end{array}$ & $\begin{array}{c}\text { African Journal of } \\
\text { Research in } \\
\text { Mathematics, } \\
\text { Science and } \\
\text { Technology } \\
\text { Education }\end{array}$ & $\begin{array}{c}\text { Bridging the Theory-Practice Divide: Life } \\
\text { Sciences Student Teachers' Perceptions of } \\
\text { Teaching in Communities of Practice at a } \\
\text { Teaching School }\end{array}$ & [24] \\
\hline A6 & 2019 & $\begin{array}{l}\text { Lavonen, } \\
\text { Henning, } \\
\text { Petersen, Loukomies, } \\
\text { Myllyviita, }\end{array}$ & $\begin{array}{l}\text { European Journal } \\
\text { of Teacher } \\
\text { Education }\end{array}$ & $\begin{array}{l}\text { A comparison of student teacher learning } \\
\text { from practice in university-affiliated } \\
\text { schools in Helsinki and Johannesburg }\end{array}$ & [25] \\
\hline A7 & 2019 & $\begin{array}{l}\text { Ngibe, } \\
\text { Pylman, } \\
\text { Mammen, } \\
\text { Adu, }\end{array}$ & $\begin{array}{l}\text { Journal of Human } \\
\text { Ecology }\end{array}$ & $\begin{array}{l}\text { Turning pre-service school experience } \\
\text { challenges into strengths }\end{array}$ & [26] \\
\hline A8 & 2019 & John & $\begin{array}{l}\text { South African } \\
\text { Journal of } \\
\text { Education }\end{array}$ & $\begin{array}{l}\text { Physical sciences teaching and learning in } \\
\text { Eastern Cape rural schools: Reflections of } \\
\text { pre-service teachers }\end{array}$ & [27] \\
\hline A9 & 2019 & $\begin{array}{l}\text { Booi, } \\
\text { Venkat, } \\
\text { Askew }\end{array}$ & $\begin{array}{l}\text { South African } \\
\text { Journal of } \\
\text { Education }\end{array}$ & $\begin{array}{l}\text { Difficulties in developing a curriculum for } \\
\text { pre-service science teachers }\end{array}$ & [28] \\
\hline A10 & 2019 & $\begin{array}{l}\text { Bowie, } \\
\text { Venkat, } \\
\text { Askew }\end{array}$ & $\begin{array}{c}\text { African Journal of } \\
\text { Research in } \\
\text { Mathematics, } \\
\text { Science and } \\
\text { Technology } \\
\text { Education }\end{array}$ & $\begin{array}{l}\text { Pre-service Primary Teachers' } \\
\text { Mathematical Content Knowledge: } \\
\text { An Exploratory Study }\end{array}$ & [29] \\
\hline A11 & 2018 & $\begin{array}{l}\text { Christiansen, } \\
\text { Bertram, } \\
\text { Mukeredzi }\end{array}$ & $\begin{array}{l}\text { Asia-Pacific } \\
\text { Journal of Teacher } \\
\text { Education }\end{array}$ & $\begin{array}{l}\text { Contexts and concepts: analysing learning } \\
\text { tasks in a foundation phase teacher } \\
\text { education programme in South Africa }\end{array}$ & [30] \\
\hline A12 & 2018 & $\begin{array}{l}\text { Ramaligela, } \\
\text { Ogbonnaya, } \\
\text { Mji. }\end{array}$ & $\begin{array}{l}\text { Africa Education } \\
\text { Review }\end{array}$ & $\begin{array}{c}\text { Comparing Pre-Service Teachers' PCK } \\
\text { through 9E Instructional Practice: A Case } \\
\text { of Mathematics and Technology } \\
\text { Pre-Service Teachers }\end{array}$ & [31] \\
\hline
\end{tabular}


Table A1. Cont.

\begin{tabular}{|c|c|c|c|c|c|}
\hline Code & Year & Authors & Journal & Title & Reference \\
\hline A13 & 2018 & Jita & $\begin{array}{l}\text { Journal of } \\
\text { Education }\end{array}$ & $\begin{array}{l}\text { Exploring pre-service teachers' } \\
\text { opportunities to learn to teach science with } \\
\text { ICTs during teaching practice }\end{array}$ & [32] \\
\hline A14 & 2018 & $\begin{array}{l}\text { Botha, } \\
\text { Baxen. }\end{array}$ & $\begin{array}{l}\text { Journal of } \\
\text { Education for } \\
\text { Teaching }\end{array}$ & $\begin{array}{l}\text { Insights from South African students } \\
\text { preparing for early childhood teaching: } \\
\text { contexts neglected in teacher preparation }\end{array}$ & [33] \\
\hline A15 & 2016 & Jita & $\begin{array}{l}\text { Perspectives in } \\
\text { Education }\end{array}$ & $\begin{array}{c}\text { Pre-service teachers' competence to teach } \\
\text { science through information and } \\
\text { communication technologies in } \\
\text { South Africa }\end{array}$ & {$[34]$} \\
\hline A16 & 2015 & Pillay & $\begin{array}{l}\text { Education as } \\
\text { Change }\end{array}$ & $\begin{array}{l}\text { Transformative and critical education } \\
\text { praxis in a teacher education lecture room }\end{array}$ & [35] \\
\hline A17 & 2015 & $\begin{array}{l}\text { Ogunniyi, } \\
\text { Rollnick }\end{array}$ & $\begin{array}{l}\text { Journal of Science } \\
\text { Teacher Education }\end{array}$ & $\begin{array}{l}\text { Pre-service Science Teacher Education in } \\
\text { Africa: Prospects and Challenges }\end{array}$ & [36] \\
\hline A18 & 2015 & $\begin{array}{c}\text { Mudaly, } \\
\text { Pithouse-Morgan, } \\
\text { Van Laren, } \\
\text { Singh, } \\
\text { Mitchell }\end{array}$ & $\begin{array}{l}\text { Perspectives in } \\
\text { Education }\end{array}$ & $\begin{array}{l}\text { Connecting with pre-service teachers' } \\
\text { perspectives on the use of digital } \\
\text { technologies and social media to teach } \\
\text { socially relevant science }\end{array}$ & [37] \\
\hline A19 & 2015 & $\begin{array}{l}\text { Beylefeld, } \\
\text { Le Roux }\end{array}$ & $\begin{array}{l}\text { Perspectives in } \\
\text { Education }\end{array}$ & $\begin{array}{l}\text { Guided group reflections of first-year } \\
\text { pre-service teachers: Moving beyond the } \\
\text { rhetoric of "go and reflect" }\end{array}$ & [38] \\
\hline A20 & 2015 & $\begin{array}{l}\text { Gravett, } \\
\text { Ramsaroop }\end{array}$ & $\begin{array}{l}\text { Perspectives in } \\
\text { Education }\end{array}$ & $\begin{array}{l}\text { Bridging theory and practice in teacher } \\
\text { education: Teaching schools-A bridge } \\
\text { too far? }\end{array}$ & [39] \\
\hline A21 & 2014 & Heeralal & $\begin{array}{l}\text { Mediterranean } \\
\text { Journal of Social } \\
\text { Sciences }\end{array}$ & $\begin{array}{c}\text { Preparing pre-service teachers to teach in } \\
\text { rural schools }\end{array}$ & {$[40]$} \\
\hline A22 & 2013 & $\begin{array}{l}\text { Zezekwa, } \\
\text { Mudau, } \\
\text { Nkopodi }\end{array}$ & $\begin{array}{l}\text { Mediterranean } \\
\text { Journal of Social } \\
\text { Sciences }\end{array}$ & $\begin{array}{l}\text { A comparative study of South African and } \\
\text { Zimbabwean science teacher education } \\
\text { programmes: Some theoretical reflections }\end{array}$ & {$[41]$} \\
\hline A23 & 2012 & $\begin{array}{l}\text { Hardman, } \\
\text { Abd-Kadir, } \\
\text { Tibuhinda }\end{array}$ & $\begin{array}{l}\text { International } \\
\text { Journal of } \\
\text { Educational } \\
\text { Development }\end{array}$ & Reforming teacher education in Tanzania & [42] \\
\hline A24 & 2011 & $\begin{array}{l}\text { Chikoko, } \\
\text { Gilmour, } \\
\text { Harber, } \\
\text { Serf }\end{array}$ & $\begin{array}{l}\text { Journal of } \\
\text { Education for } \\
\text { Teaching }\end{array}$ & $\begin{array}{l}\text { Teaching controversial issues and teacher } \\
\text { education in england and South Africa }\end{array}$ & [43] \\
\hline A25 & 2011 & $\begin{array}{l}\text { Ijaiya, } \\
\text { Alabi, } \\
\text { Fasasi }\end{array}$ & $\begin{array}{l}\text { Research Journal } \\
\text { of Business } \\
\text { Management }\end{array}$ & $\begin{array}{l}\text { Teacher education in africa and critical } \\
\text { thinking skills: Needs and strategies }\end{array}$ & [44] \\
\hline A26 & 2010 & Essien & $\begin{array}{l}\text { Perspectives in } \\
\text { Education }\end{array}$ & $\begin{array}{c}\text { What teacher educators consider as best } \\
\text { practices in preparing pre-service teachers } \\
\text { for teaching Mathematics in multilingual } \\
\text { classrooms }\end{array}$ & [45] \\
\hline A27 & 2008 & Van Laren & $\begin{array}{c}\text { African Journal of } \\
\text { Research in } \\
\text { Mathematics, } \\
\text { Science and } \\
\text { Technology } \\
\text { Education }\end{array}$ & $\begin{array}{c}\text { Exploration of strategies to integrate hiv } \\
\text { and aids education in pre-service teacher } \\
\text { education }\end{array}$ & [46] \\
\hline
\end{tabular}


Table A1. Cont.

\begin{tabular}{ccccc}
\hline Code & Year & Authors & Journal & Title \\
\hline A28 & 2006 & $\begin{array}{c}\text { Robinson, } \\
\text { McMillan }\end{array}$ & $\begin{array}{c}\text { Teaching and } \\
\text { Teacher Education }\end{array}$ & $\begin{array}{c}\text { Who teaches the teachers? Identity, } \\
\text { discourse and policy in teacher education }\end{array}$ \\
\hline A29 & 2003 & Robinson & $\begin{array}{c}\text { Journal of } \\
\text { Education for } \\
\text { Teaching }\end{array}$ & $\begin{array}{c}\text { Teacher education policy in South Africa: } \\
\text { The voice of teacher educators }\end{array}$ \\
\hline A30 & 2002 & $\begin{array}{c}\text { Akyeampong } \\
\text { Stephens }\end{array}$ & $\begin{array}{c}\text { International } \\
\text { Journal of } \\
\text { Educational } \\
\text { Development }\end{array}$ & $\begin{array}{c}\text { Exploring the backgrounds and shaping of } \\
\text { beginning student teachers in Ghana: } \\
\text { Toward greater contextualisation of } \\
\text { teacher education }\end{array}$ \\
\hline A31 & International & $\begin{array}{c}\text { Journal of } \\
\text { Educational } \\
\text { Development }\end{array}$ & $\begin{array}{c}\text { Working in the rain: Pressures and } \\
\text { priorities for teacher education curriculum } \\
\text { design in South Africa: A case study of the } \\
\text { University of Durban-Westville }\end{array}$ \\
\hline
\end{tabular}

\section{References}

1. Akkari, A. The new international agenda for education 2030: Soft consensus or a tool for mobilization of education's actors in the XXI century? Rev. Diálogo Educ. 2017, 17, 937-958.

2. Kyle, W.C. Expanding our views of science education to address sustainable development, empowerment, and social transformation. Discip. Interdiscip. Sci. Educ. Res. 2020, 2, 2. [CrossRef]

3. Mnguni, L. A theoretical framework for training science teachers in the 21st century to enhance social accountability in poor communities. J. Educ. Young Sci. 2019, 159-175.

4. UNESCO. Education 2030: Incheon Declaration and Framework for Action towards Inclusive and Equitable Quality Education and Lifelong Learning for All; UNESCO: Paris, France, 2016.

5. AUC (African Union Commission). Agenda 2065-The Africa We Want; AUC: Addis Ababa, Ethiopia, 2015.

6. African Union Headquarters. Continental Education Strategy for Africa 2016-2025. 2016, 1-44. Available online: http://hrst.au. int/en/sites/default/ files/CESA-English-V9.pdf (accessed on 30 April 2021).

7. Moja, T. Nigerian Education Sector Analysis: An Analytical Synthesis of Performance and Main Issues. In World Bank Monograph Series; NUC, Ed.; World Bank: Abuja, Nigeria, 2000; Volume 1.

8. Chissingui, A.V.; Costa, N. Teacher education and sustainable development goals: A case study with future biology teachers in an Angolan higher education institution. Sustainability 2020, 12, 3344. [CrossRef]

9. Ogunniyi, M.B. The development of science education in Botswana. Sci. Educ. 1995, 79, 95-109. [CrossRef]

10. Jones, N.; Bailey, M.; Lyytikäinen, M. Research Capacity Strengthening in Africa: Trends, Gaps and Opportunities; Overseas Development Institute: London, UK, 2007.

11. Marjanovic, S.; Hanlin, R.; Diepeveen, S.; Chataway, J. Research capacity-building in Africa: Networks, institutions and local ownership. J. Int. Dev. 2013, 25, 936-946. [CrossRef]

12. Hodson, D. Time for action: Science education for an alternative future. Int. J. Sci. Educ. 2003, 36, 645-670. [CrossRef]

13. Lopes, B.; Almeida, P.; Martinho, M.; Capelo, A. What do we learn when we teach abroad? Reflections about International Cooperation. Procedia Social Behav. Sci. 2014, 116, 3930-3934. Available online: https://www.sciencedirect.com/science/article/ pii/S1877042814008866?via\%3Dihub (accessed on 30 April 2021). [CrossRef]

14. Guthrie, G. Classroom Change in Sub-Saharan Africa in Foundations Classroom Change in Developing Countries, Volume 1: Evidence; Gerard Guthrie. Available online: https:/ / www.researchgate.net/publication/349094827 (accessed on 30 April 2021).

15. Guthrie, G. Classroom Change in Sub-Saharan Africa in Foundations Classroom Change in Developing Countries, Volume 2: Synthesis; Gerard Guthrie. Available online: https:/ /www.researchgate.net/publication/349094827 (accessed on 30 April 2021).

16. Amado, J. Manual de Investigação Qualitativa em Educação, 2nd ed.; Imprensa da Universidade de Coimbra: Coimbra, Portugal, 2014.

17. Apple, M.W. Ideology and Curriculum, 3rd ed.; Routledge Falmer: New York, NY, USA; London, UK, 2004.

18. Santomé, J.T. El Curriculum Oculto, 11th ed.; Morata: Madrid, Spain, 1998.

19. Pinar, W. What is Curriculum Theory? Lawrence Erlbaum Associates: Mahwah, NJ, USA, 2004.

20. Silva, T.T. Documentos de Identidade: Uma Introdução às Teorias do Currículo; Edições Pedago: Odivelas, Portugal, 2011.

21. Humphreys, S.; Dunne, M.; Durrani, N.; Sankey, S.; Kaibo, J. Becoming a teacher: Experiences of female trainees in initial teacher education in Nigeria. Teach. Teach. Educ. 2020, 87, 102957. [CrossRef]

22. Ramaligela, S.M. Exploring pre-service technology teachers' content and instructional knowledge to determine teaching readiness. Int. J. Technol. Des. Educ. 2020, 1-14. [CrossRef]

23. Buckler, A. Being and becoming in teacher education: Student-teachers' freedom to learn in a College of Education in Ghana. Comp. A J. Comp. Int. Educ. 2019, 50, 844-864. [CrossRef] 
24. Van Wyk, G.; De Beer, J. Bridging the Theory-Practice Divide: Life Sciences Student Teachers' Perceptions of Teaching in Communities of Practice at a Teaching School. Afr. J. Res. Math. Sci. Technol. Educ. 2019, 23, 276-285. [CrossRef]

25. Lavonen, J.; Henning, E.; Petersen, N.; Loukomies, A.; Myllyviita, A. A comparison of student teacher learning from practice in university-affiliated schools in Helsinki and Johannesburg. Eur. J. Teach. Educ. 2018, 42, 4-18. [CrossRef]

26. Ngibe, N.C.P. Turning Pre-service School Experience Challenges into Strengths. J. Hum. Ecol. 2019, 66, 33-44. [CrossRef]

27. John, M. Physical sciences teaching and learning in Eastern Cape rural schools: Reflections of pre-service teachers. S. Afr. J. Educ. 2019, 39, S1-S12. [CrossRef]

28. Booi, K.; Khuzwayo, M.E. Difficulties in developing a curriculum for pre-service science teachers. S. Afr. J. Educ. 2019, 39, 1-13. [CrossRef]

29. Bowie, L.; Venkat, H.; Askew, M. Pre-service Primary Teachers' Mathematical Content Knowledge: An Exploratory Study. Afr. J. Res. Math. Sci. Technol. Educ. 2019, 23, 286-297. [CrossRef]

30. Christiansen, I.; Bertram, C.; Mukeredzi, T. Contexts and concepts: Analysing learning tasks in a foundation phase teacher education programme in South Africa. Asia Pac. J. Teach. Educ. 2018, 46, 511-526. [CrossRef]

31. Ramaligela, S.M.; Ogbonnaya, U.I.; Mji, A. Comparing Pre-Service Teachers' PCK Through 9E Instructional Practice: A Case of Mathematics and Technology Pre-Service Teachers. Afr. Educ. Rev. 2018, 16, 1-16. [CrossRef]

32. Jita, T. Exploring pre-service teachers' opportunities to learn to teach science with ICTs during teaching practice. J. Educ. 2018, 73-90. [CrossRef]

33. Botha, L.J.; Baxen, J. Insights from South African students preparing for early childhood teaching: Contexts neglected in teacher preparation. J. Educ. Teach. 2018, 44, 446-460. [CrossRef]

34. Jita, T. Pre-service teachers' competence to teach science through information and communication technologies in South Africa. Perspect. Educ. 2016, 34, 15-28. [CrossRef]

35. Pillay, A. Transformative and critical education praxis in a teacher education lecture room. Educ. Chang. 2015, 19, 4-23. [CrossRef]

36. Ogunniyi, M.B.; Rollnick, M. Pre-service Science Teacher Education in Africa: Prospects and Challenges. J. Sci. Teach. Educ. 2015, 26, 65-79. [CrossRef]

37. Mudaly, R.; Pithouse-Morgan, K.; Van Laren, L.; Singh, S.; Mitchell, C. Connecting with pre-service teachers' perspectives on the use of digital technologies and social media to teach socially relevant science. Perspect. Educ. 2015, 33, $23-41$.

38. Beylefeld, A.; Roux, A.L. Guided group reflections of first-year pre-service teachers: Moving beyond the rhetoric of "go and reflect". Perspect. Educ. 2015, 33, 1-19.

39. Gravett, S.; Ramsaroop, S. Bridging theory and practice in teacher education: Teaching schools-A bridge too far? Perspect. Educ. 2015, 33, 131-146.

40. Heeralal, P.J.H. Preparing pre-service teachers to teach in rural schools. Mediterr. J. Soc. Sci. 2014, 5, 1795-1799. [CrossRef]

41. Zezekwa, N.; Mudau, A.V.; Nkopodi, N. Developing a Theoretical Model for Investigating the Mathematics and Science Teachers' Pck in South Africa and Zimbabwe. Mediterr. J. Soc. Sci. 2013, 4, 317-324. [CrossRef]

42. Hardman, F.; Abd-Kadir, J.; Tibuhinda, A. Reforming teacher education in Tanzania. Int. J. Educ. Dev. 2012, 32, 826-834. [CrossRef]

43. Chikoko, V.; Gilmour, J.D.; Harber, C.; Serf, J. Teaching controversial issues and teacher education in England and South Africa. J. Educ. Teach. 2011, 37, 5-19. [CrossRef]

44. Ijaiya, N.; Alabi, A.; Fasasi, Y. Teacher Education in Africa and Critical Thinking Skills: Needs and Strategies. Res. J. Bus. Manag. 2009, 5, 26-34. [CrossRef]

45. Essien, A.A. What teacher educators consider as best practices in preparing pre-service teachers for teaching Mathematics in multilingual classrooms. Perspect. Educ. 2010, 28, 32-42.

46. Van Laren, L. Exploration of strategies to integrate HIV and AIDS education in pre-service teacher education. Afr. J. Res. Math. Sci. Technol. Educ. 2008, 12, 47-61. [CrossRef]

47. Robinson, M.; McMillan, W. Who teaches the teachers? Identity, discourse and policy in teacher education. Teach. Teach. Educ. 2006, 22, 327-336. [CrossRef]

48. Robinson, M. Teacher Education Policy in South Africa: The voice of teacher educators. J. Educ. Teach. 2003, 29, 19-34. [CrossRef]

49. Akyeampong, K.; Stephens, D. Exploring the backgrounds and shaping of beginning student teachers in Ghana: Toward greater contextualisation of teacher education. Int. J. Educ. Dev. 2002, 22, 261-274. [CrossRef]

50. Samuel, M. Working in the rain: Pressures and priorities for teacher education curriculum design in South Africa: A case study of the University of Durban-Westville. Int. J. Educ. Dev. 2002, 22, 397-410. [CrossRef] 